\title{
Research on Chinese Film and Television Cultural Products Policy under the Belt and Road Initiative
}

\author{
Jing Wang \\ Xi’an Peihua University, Xi’an, Shannxi, 710125
}

Keywords: The Belt and Road, Chinese Film, Television Cultural Products

\begin{abstract}
The Belt and Road" is not just a road to economic development, but it also carries the cultural memory of countries along the country. The implementation of "The Belt and Road" initiative should not only pay attention to economic exchange, but also focus on promoting the interaction between Chinese culture and national culture along the Silk Road. The film and television products "going out" into the "The Belt and Road" overall strategic layout, not only brings some economic benefits, but also enhances the influence of film and television culture, promotes the development of China's film culture industry. On the basis of reviewing the status quo of "going out" of China's film and television cultural products, this paper explores the new opportunities and new strategies brought by the development of China's film and television industry.
\end{abstract}

\section{Introduction}

As an important tool for transmitting national culture and spreading the mainstream ideology of the country, radio, film and television are related to social stability and national cultural and information security and are important national strategic industries. Radio and television channels and frequency resources are the strategic resources of a country. They are generally controlled by the state and strictly controlled. Only because of the different national conditions, some state-run monopolies and some state-owned ownership and the right to operate separately. Radio, film and television not only have strong publicity, but also generate enormous economic benefits. For example, the developed countries such as the United States, Britain, France, Germany and Japan have become their important industrial sectors and become the new growth point of the national economy and pillar industries. This feature determines that our radio, film and television must take the public financial policy-led as the dominant, at the same time absorbing the necessary non-public capital and foreign capital as a supplement to ensure the country's cultural information security [1].

As an important carrier of cultural transmission, radio, film and television are technology-intensive and capital-intensive industries that require tremendous capital investment to keep up with the trend of new technology in the world. Taking the ongoing digital television as an example, according to the calculations by the parties concerned, it will take about 160 billion yuan to realize the national analogue television to digital television conversion, and an annual market scale of about 600 billion yuan will be formed. Investment in public finance alone is far behind not enough. To this end, we must make greater efforts to invest in public finance while invigorating the mechanism for investment and financing to truly achieve this goal.

The institutional characteristics of radio, film and television in our country are that the cause is the main body and that the industry is a branched compound system. In order to ensure radio, film and television as the "mouthpiece" function of the party and the country, China's radio, film and television industry has been implementing the system of "business system and enterprise operation" for a long time, of which the movie industry has now achieved industrialized operation. This kind of undertaking is the mainstay and the industry is a branched compound system, which is a specific form of the transition from planned economy to market economy and helps to safeguard the country's cultural information security. However, in financial management, foreign investment and financing cooperation and corporate governance structure There are many difficult problems to be solved. It is necessary to clarify the boundary between business and industry through classification 
reform so that radio and film and television can not only undertake the public service function but also speed up the industrialization.

\section{Chinese cultural products export status and characteristics}

Since the mid-1980s, China's cultural trade started relatively slowly. However, the export of cultural products in the true sense took place in the mid-to-late 1990s. With the rise of commercial films and the rise of processing trade in foreign cultural products Developed After several years of accumulated experience, after China joined the WTO, China's exports of cultural products gradually took the fast lane and became a rapidly growing department for foreign trade [2].

Since China joined the WTO, the trade pattern of China's cultural products has been relatively stable, and the scale of export of general trade and processing trade has been basically equal. Judging from the contribution rates of the two major trade modes to the overall export of cultural products, the average contribution rate of general trade exports was relatively high at $51.3 \%$ in only five years of accession to the WTO and the export contribution rate of processing trade was $41.1 \%$. In 2007, the export of cultural products in our country continued to grow. Among them, 2.91 billion U.S. dollars was exported from processing trade, an increase of $39.9 \%$, accounting for $47.2 \%$ of the total export of cultural products of the year and 2.91 billion U.S. dollars from the export of cultural products in general trade, an increase of $21.5 \%$. In general, the general trade embodies the independent R \& D and manufacturing capabilities, while the processing trade reflects the processing capacity. Therefore, the relatively stable trade pattern in our country shows that the export of cultural products in our country basically accomplishes both the development of cultural products and the processing of cultural products, Reflecting the good development status of cultural industries in the construction of cultural innovation ability and effective employment absorption.

\section{The "the Belt and Road" Initiative brings new opportunities for "going global" for television products}

Different countries have different degrees of economic development and different social and political backgrounds, making the cultures of all countries and regions diverse and diverse. This has also led to the phenomenon of "cultural discount" in the consumption of cultural goods by other overseas audiences. This is the main bottleneck of China's cultural and cultural products going out. The once ancient Silk Road played a very important role in promoting the exchange of ideas between China and the West, cultural integration, economic cooperation and the diversification of human civilization. Through the Silk Road business camel caravan, Chinese literature, academic ideas and other Chinese civilization spread to many countries in the world. At the same time, various Western civilizations such as philosophy, astronomy and religion in the West have also been introduced to China along "The Belt and Road." The cultural exchanges on the Silk Road greatly influence the way of thinking and way of life between countries [3].

Film and television culture needs a vast market, the more extensive the main consumer, the greater the market for the export of film and television products, the greater the cultural influence. China's exports of movies and television shows have been sluggish for a long time and have had serious trade deficits with developed countries in Europe, the United States, Japan and South Korea. These countries have relatively high levels of film and television culture industry output and relatively high output of film and television culture. On the inherent cultural preferences, making these areas has become China's film and television products can not enter the "restricted area." The "The Belt and Road" strategy involves a total population of about 4.4 billion, accounting for $63 \%$ of the world's total economic output of about 21 trillion U.S. dollars, accounting for about $29 \%$ of the world. Most of the countries along the line are emerging economies and developing countries, covering most of Central Asia, South Asia and most of Southeast Asia, but also extending to West Asia, Europe and Africa. This is undoubtedly the export of cultural products such as Chinese films and TV dramas, the film and television culture Foreign communication provides a new historical opportunity. 
Since the "The Belt and Road" strategy has been put forward, with the Silk Road Film Festival, Film Forum and other activities held to improve China's export share of film and television initiatives have begun to bear fruit. According to the data released at the 2015 Silk Road Film and Television Bridge International Cooperation Summit, in 2014 China's film and television products were exported to over 100 countries and regions [4]. The overseas sales of film and television programs exceeded 10,000 hours and the overseas box office receipts were 18. 700 million yuan, exports of television cultural products and services amounted to 1.2 billion U.S. dollars.

After the strategy of "The Belt and Road" was put forward, in order to better explain its proposition and connotation and promote the implementation of "The Belt and Road" major initiative, our government formulated and promulgated the "Promote the Building of the Silk Road Economic Belt and the 21st Century Vision and Action of the Maritime Silk Road. " The program sets forth such topics as "organizing cultural activities, art festivals, film festivals, television weekly and book exhibitions among countries along the line, and collaborating on the creation and translation of radio and television drama series." The Belt and Road strategy has increased support for the "going global" of Chinese film and television products from the national level, and has integrated the external transmission of Chinese film culture into the overall layout. In 2014, our country broadened the market scope of the export of film and television products and enriched the culture of film and television overseas through such platforms as high-level exchange visits with the governments of the Silk Road, media cooperation, radio and television cooperation forums and the Silk Road Film and Television Bridge project. Diversified forms of communication.

\section{Promote China's film and television cultural products "going global" strategy}

Film and television products export huge cultural value can not be separated from the national level of support. In the United States, France, South Korea and other countries, cultural products "go global" are all state actions in the first place. The state strongly supports "output" of culture in terms of manpower, material and financial resources, especially in the export of cultural and cultural products. For example, the "Korean Wave" triggered by the export of Korean plays is closely linked with many preferential policies that the Korean government encourages the export of Korean drama. In order to support the production of the drama, the government provides production funds at no expense; in order to support the export of television programs overseas, the government will apply for post-production costs for export. After the government has applied for it, it will provide enterprises with $80 \%$ of the funds. In order to support Korean TV and Korean TV companies to sell home-made TV dramas and television programs abroad, the Korean government will attend the festival Businesses provide free air tickets.

Countries along the "The Belt and Road" have different cultural traditions and customs. The modes of thinking and lifestyles of countries vary greatly from country to country. We must study the customs, customs, cultural origins, aesthetic taste and customs of each country along the country. It is necessary to fully consider the consumption habits of film and television under all kinds of cultural backgrounds, study the cultural traditions, values and reception psychology of different audience groups, find out their concerns and points of interest, and then make targeted marketing of films and TV programs Cultural products, the "Chinese story", "China Voice" into the film and television works to better spread Chinese culture [5].

There are cultural similarities between neighboring countries in Asia and our country. They are deeply influenced by the Chinese culture, have little market development resistance and are more easily accepted by the country. Therefore, the markets in neighboring countries are the basis for our country's development of cultural industries and cultural trade. However, taking into account that the peripheral markets are mostly developing countries, the market capacity and spending power are not strong, and vigorously developing markets in the developed countries in Europe and the United States is the long-term goal of China's cultural trade. In particular, the victory of the Olympic Games has won a huge international reputation for our country and created a good atmosphere for the smooth entry of Chinese cultural products into the markets of Europe and the United States. Relevant departments should actively organize and carry out exchanges and exhibitions of various 
cultural products, create a display platform for domestic cultural products, and use the commercial department of the consulate to provide commercial information for the export of corporate cultural products and guide the production of enterprises.

Under the strategic background of "The Belt and Road", culture and economy have become bridges connecting Asia with Europe. Television and movie products, as a result of the combination of commerce and culture, have ushered in a booming development. Film and television enterprises should actively strengthen exchanges and cooperation with film and television companies along the line, and through activities such as co-productions, inject new vitality into the development of enterprises and find new growth points for improving enterprise efficiency. From the perspective of film and television culture, film and television enterprises should profoundly understand and correctly handle the relationship between cultural products and their cultural values such as bearing values, customs and habits, conscientiously stick to and promote our outstanding cultural concepts and values. The Chinese culture based on the carrier of film and television products in the wider dissemination of the region to further enhance the film and television culture industry.

\section{Conclusions}

Radio, Film and Television is a technology-intensive and capital-intensive strategic industry that is related to the security of national cultural information. It requires enormous capital investment to achieve rapid development. At present, the investment and financing of radio, film and television in our country are still dominated by policy-oriented financing, supplemented by direct and indirect financing of state-owned capital, non-public capital, and foreign capital, and listed financing is a new bright spot. With the deepening of the reform of the cultural system, the gradual adjustment of the investment and financing policies should prompt China's radio, film and television to achieve rapid and healthy development in the new situation and promote the great development and prosperity of culture.

\section{References}

[1] Luan Yimei. Strong new joint media experiment: radio and network hand in hand [J]. China Radio and Television Academic 1999 (01): 62-67.

[2] Lin Xingren. Analysis of the "Cultural Revolution" broadcast body [J]. Modern Communications. 1989 (Z1): 83-85.

[3] Xu Jiarui. Ten drama drama stage "Week drama radio conference" 800 Sidelights [J]. Shanghai Theater. 2011 (01): 95-99.

[4] Week July. Study on the Creative Function of Broadcasting Voices [J]. China Cultural Forum. 2008 (01): 101-16.

[5] Wu Deli. Demolition of the wall between the drama radio and the audience [J]. Opera Art. 1998 (03): 43-47. 